1 US Department of Health and Human Services. Chlamydia trachomatis infections. Policy guidelines for prevention and control. US Department of Health and Human Services. Atlanta, Georgia: Centers for Disease Control, 1985.

2 Bernal JN, Martineq MA, Dabancens A. Evaluation of proposed cytomorphologic criteria for the diagnosis of Chlamydia trachomatis in Papanicolaou smears. Acta Cytol 1988;33:309-13.

3 Kiviat NB, Paavonen JA, Wolner-Hansen P, et al. Histopathology of endocervical infection caused by Chlamydia trachomatis, herpes simplex virus, Trichomonas vaginali and Neisseria gonorrhoeae. Hum Pathol 1990;21:831-7.

4 Dunlop EMC, Garner A, Darougar S, Treharne JD, Woodland RM. Colposcopy, biopsy, and cytology results in women with chlamydial cervicitis. Genitourin Med
1989;65:22-31.

5 Kiviat NB, Peterson M, Kinney-Thomas E, Tam M, Stamm WE, Holmes KK. Cytological manifestations of cervical and vaginal infections. $J A M A$ 1985;253:997-1000

6 Leopardi $O$, Celentano C, Naughten $W$. Immunoperoxidase demonstration of chlamydia inclusions in routine Pap

7 Caul EO, Paul ID, Milner JD, Crowley T. Non-invasive sampling method for detecting Chlamydia trachomatis. Lancet 1988;ii:1246-7.

8 Lundermose AG, Lundemose JB, Birkelund S, Christiansen $G$. Detection of chlamydia in postmortal formalin fixed tissue. APMIS 1989;97:68-74.

9 Barnes RC. Laboratory diagnosis of human chlamydial infections. Clin Microbiol Rev 1989;2:119-36.

\title{
Evaluation of a screening test for detecting urinary tract infection in newborns and infants
}

\author{
B Lejeune, R Baron, B Guillois, D Mayeux
}

Microbiology and
Public Health
Laboratory, CHU
Morvan - 29609 Brest
Cedex France
B Lejeune
R Baron
Department of
Paediatrics, CHU
Morvan
B Guillois
Medical Computer
Laboratory, Faculty of
Medecine, Les Nancy
France
D Mayeux
Correspondence to:
Dr B Lejeune
Accepted for publication 22
May 1991

\section{Abstract}

The results of a study of a screening test for urinary tract infection (UTI) in infants under 18 months is reported. Two hundred and forty three urine specimens were tested in the laboratory using AMES Multistix 8SG reagent strips read by photometer. The strips included three potential markers for urinary tract infection: leucocyte esterase, nitrite, and protein. The predictive value of a positive result (PPV) was low. The predictive value of negative test (NPV) when combining the screen of leucocyte esterase, nitrite, and protein was $\mathbf{9 9 . 4 \%}$ with no difference between boys and girls. The test for leucocyte esterase had a $97.6 \%$ negative predictive value. An examination of the results by age confirms the good NPV in all age groups.

Paediatricians should find Multistix 8SG strips a useful aid in the diagnosis of urinary tract infection in infants, and that costly culture of samples with negative strip tests can be avoided.

Boreland and colleagues reported the diagnostic value of a screening test for urinary tract infection in paediatric inpatients using three tests: nitrite, blood, and protein. ${ }^{1}$ We studied consecutive urine samples from 243 neonates and infants under 18 months: 85 were less than 28 days old; 81 aged between 21 and 182 days; and 77 were more than 182 days old. Our aim was to identify the dipstick test which gave the highest diagnostic accuracy in routine practice for this age group and to evaluate the leucocyte esterase test.

\section{Method}

Urine reagent strips for nitrite, leucocyte esterase, and protein were used (Multistick 8 SG AMES) and read by the Clinitek System photometer (AMES). All screening tests were performed by the same investigator in our laboratory. All samples were microscopically examined, cultured, and bacteria enumerated (DGU Institut Pasteur Production, France). The criteria for diagnosis of urinary tract infection ${ }^{2}$ were as follows: a combination of a white cell count of $>25 \times 10^{9} / 1$ for boys or 50 $\times 10^{9} / 1$ for girls under 8 days of age; $>10 \times 10^{9} / 1$ for those older than 8 days; and a bacterial count of $>10^{5} \mathrm{ml}^{-1}$ with a maximum of two bacterial species. Samples with $10^{4} / \mathrm{ml}^{-1}$ or less, or those with more than two bacterial species were considered contaminated.

The statistical analysis of the screening tests results was based on Baye's tests and compared with the criteria for diagnosis of urinary tract infection.

\section{Results}

Thirty seven $(15.2 \%)$ specimens met the criteria for bacteriological infection, and 81 $(33 \%)$ were regarded as contaminated. One hundred and forty six $(60 \%)$ specimens were negative by the strip test and 97 were positive for one or more of leucocyte esterase, nitrate, or protein. The percentage of false negative results was $1.6 \%$ (four urine specimens) and was attributed to asymptomatic infection $\left(>10^{5} / \mathrm{ml}^{-1}\right)$ after review of the medical records.

The negative predictive value (NPV) obtained with the combination of leucocyte esterase and protein, and with the combination of leucocyte esterase, nitrite, and protein 
Efficacy (in per cent) of screening test in neonates and infants

\begin{tabular}{|c|c|c|c|c|}
\hline Positive test area & Sensitivity & Specificity & $\begin{array}{l}\text { Positive } \\
\text { predictive } \\
\text { value }\end{array}$ & $\begin{array}{l}\text { Negative } \\
\text { predictive } \\
\text { value }\end{array}$ \\
\hline \multirow{2}{*}{$\begin{array}{l}\text { Leucocyte esterase } \\
\text { Nitrite } \\
\text { Protein } \\
\text { Leucocyte esterase and nitrite } \\
\text { Leucocyte esterase and protein } \\
\text { Leucocyte esterase and nitrite } \\
\text { and protein }\end{array}$} & $\begin{array}{r}89 \cdot 2 \\
16 \cdot 2 \\
8 \cdot 1 \\
89 \cdot 2 \\
89 \cdot 2\end{array}$ & $\begin{array}{l}78 \cdot 2 \\
97 \cdot 6 \\
95 \cdot 1 \\
97 \cdot 6 \\
95 \cdot 1\end{array}$ & $\begin{array}{l}42 \cdot 3 \\
54 \cdot 5 \\
23 \cdot 1 \\
87 \cdot 2 \\
76 \cdot 7\end{array}$ & $\begin{array}{l}97 \cdot 6 \\
86 \cdot 6 \\
85 \cdot 2 \\
98 \cdot 5 \\
98 \cdot 0\end{array}$ \\
\hline & $89 \cdot 2$ & $71 \cdot 8$ & $36 \cdot 3$ & $99 \cdot 4$ \\
\hline
\end{tabular}

was highest (table), but the NPV of leucocyte esterase alone did not differ significantly. The nitrite test alone showed a low sensitivity and the highest specificity. The result of this test when combined with leucocyte esterase and protein did not provide additional information in infants with urinary tract infection, contrary to the results obtained from adult patients. $^{1}$

\section{Conclusion}

We have confirmed the value of urine strips as a screening test to exclude diagnosis of urinary tract infection among inpatient infants. We recommend that the test is done at the bedside using photometry to avoid the variations due to readings by nurses. The most important aspect of the test is the NPV, detection of leucocyte esterase alone or in combination with proteinuria or detection of nitrite having the most value.

The absence of leucocyturia, proteinuria, or a positive nitrite test practically excludes the diagnosis of urinary tract infection among infants and in our hospital urine cultures on infants could be reduced by $60 \%$ on the basis of this screening test.

1 Boreland PC, Stoker M. Dipstick analysis for screening of pediatric urine. J Clin Pathol 1986;39:1360-2.

2 Klein JO, Marcy SM. Infections of the urinary tract. In: Infectious diseases of the fetus and newborn infant. Philadelphia: WB Saunders Company, 1976:841-53.

\title{
Oncocytic metaplasia of the nasopharynx or extra-parotid Warthin's tumour?
}

\author{
A P Griffiths, P Dekker
}

\begin{abstract}
A case of oncocytic metaplasia obstructing the Eustachian tube in an elderly patient is described. Histologically, it was similar to Warthin's tumour of the parotid gland. The lymphocytes were predominantly $T$ cell, unlike those of Warthin's tumour which are predominantly $B$ cell. It is proposed that oncocytic metaplasia represents an early stage in the evolution of Warthin's tumour.
\end{abstract}

Warthin's tumour, or adenolymphoma, occurs almost exclusively in the parotid gland ${ }^{1-3}$ where it accounts for $8 \%$ of tumours. ${ }^{2}$ Outside the parotid, it has been reported in juxtaparotid lymph nodes, the submandibular gland and, very rarely, in minor salivary glands of palate, cheek, lip and tongue. ${ }^{45}$ Lesions of identical histological appearance occur in the nasopharynx and could be mistaken for a rare example of extra-parotid Warthin's tumour. Friedmann, however, attributed the histological appearances of this lesion from the post-nasal space to a combination of chronic inflammation and hyperplasia of mucous glands, denying that it constituted a "true tumour".

\section{Case report}

An 81 year old woman presented with leftsided otalgia and conductive hearing loss. A raised red plaque was present, obstructing the pharyngeal ostium of the left Eustachian tube. This was excised. The gross specimen consisted of a mucosal ellipse $0.5 \times 1.0 \mathrm{~cm}$ and $0.9 \mathrm{~cm}$ thick. Histological examination showed a well circumscribed, though not encapsulated, nodule of tissue $0.8 \mathrm{~cm}$ in maximum diameter with a microscopic appearance similar to that of a Warthin's tumour or adenolymphoma (fig 1). Cystically dilated ducts lined by partly infolded, double-layered oncocytic columnar epithelium were embedded in stroma rich in lymphocytes. Immunophenotyping of this lymphocytic stroma showed that these were $T$ cells (fig 2).

\section{Discussion}

The case described above and a similar recently reported case ${ }^{6}$ were both initially diagnosed as examples of extra-parotid Warthin's tumour of the nasopharynx. Both were subsequently diagnosed as oncocytic metaplasia in view of the reported rarity of Warthin's tumour in the nasopharynx. Indeed, the credibility of reports of Warthin's tumour outside the parotid is questioned by some authors. ${ }^{27}$

Oncocytic metaplasia, on the other hand, is a common occurence in both major and minor salivary glands, its incidence increasing with age. $^{2}$ When oncocytic metaplasia accompanied by dilatation of ducts occurs in close proximity to the ostium of an Eustachian tube it may cause obstruction, middle ear effusion, and 